EPOS, XIII (1997), págs. 289-302

\title{
SOCIOCULTURAL DIMENSIONS OF COMPUTERS IN LANGUAGE LEARNING: THE EUROPEAN CONTEXT
}

RAFIK LOULIDI MORTADA

UNED

GERMÁN RUIPÉREZ

UNED

\begin{abstract}
One of the major and relatively recent developments in modern education has been the attempt to incorporate technological innovations as an aid in the learning activity. More specifically, such development has been manifested to a large extent in the area of language learning and teaching. The integration of the microcomputer, for example, in the language classroom at elementary or advanced levels continues to raise the interest of a large body of teachers and educators. However, despite a widespread enthusiasm in some academic and educational circles, the absence of a theoretical basis for the integration of the computer in the classroom, on the one hand, and the lack of coordination between hardware/software producers and curriculum developers, on the other, have resulted in a rather limited role for the computer in education. This, in turn, has produced a kind of skepticism among some teachers about the potential of the computer in language learning. Drawing on current debate in the field and using concrete examples within the European context, the present article focuses on what the authors believe to be an important aspect in language learning: the role of CALL (Computer Assisted Language Learning) in enhancing cultural awareness and understanding, changing attitudes, and improving the learning process.
\end{abstract}




\section{INTRODUCTION}

In recent years, the use of the microcomputer has become widespread in many areas of social activities. This is due, in part, to a rapidly developing technology and to the relatively easy and accessible use of such machines. Dobberstein (1993: 429) argues that "computers have become a commodity technology partly because of this mass documentation, for the goal of much of it is to make the private, coded discourse of technical professionals accessible to those with no formal training in computers. Not even the advent of the automobile, which marked the previous popular revolution in technology called forth so much explication of technical matters". At the linguistic level, one may also note the preponderance of computer-related neologisms provoked by a generalized interest in computers and particularly in communication networks (e.g. multimedia, superhighways, World Wide Web, etc.). Such terminology is becoming increasingly part of the daily discourse in newspapers and other media of communication, and even in individual interaction.

In education, despite a cautious skepticism among some language teachers, there is a growing demand for the integration of the computer in the language course. This is clear, for example, in the current educational reforms in many European countries which emphasize the positive value of the incorporation of information technology in school curricula. In specialised academic circles, there is a constant effort to promote a constructive debate on the subject and provide a forum for discussion among teachers, policy makers and software developers,. This is the case, for instance, of the recently established EUROCALL (European Association for Computer Assisted Language Learning) whose aims include the promotion of the use of foreign languages in Europe; the provision of a European focus for all aspects of the use of technology for language learning; the enhancement of the quality, dissemination and efficiency of CALL materials. (cf. EUROCALL leaflet). On the other hand, the skeptical attitudes towards the use of the computer in the classroom which prevail among some teachers may be explained within a number of dimensions. One of these is the lack of basic knowledge about general information technology, which makes some teachers rather reluctant to explore an unknown area. Also they may not be entirely favourable to further training that requires more time and effort.

The argument put forward in the present article evolves around the assumption that the process of language learning can be particularly enhanced through appropriate uses of the computer. It draws essentially on the current theoretical debate in the field of CALL and also on the findings and conclusions of previous research studies in this area. The focus is not so much on the com- 
puter itself (i.e. hardware, software, etc.) but rather on the function of the computer and the role it plays for enriching the learning process, improving attitudes, and increasing the learner's motivation.

\section{EUROPEAN EDUCATION AND INFORMATION TECHNOLOGY}

The improvement of the learning and teaching of foreign languages within Europe has long been the preoccupation, at least at the official level, of national education authorities. European Community programs such as LINGUA -especially in its Action III which provides for measures to improve foreign language learning and encourage the exploitation of the newer technologies to provide greater flexibility, individualism and motivation- and DELTA (Telematic Systems for Flexible and Distance Learning) have a wide range of European funded projects involving theoretical and practical research in the large area of language and technology (cf. Commission of the European Communities, 1993a): Moreover, within each member state there is an attempt to bring forward new proposals for the adaptation of the school curriculum to the current progress made in the field of information technology.

It is important to note that recent developments in modern education systems strongly emphasize the vital role of the computer in the classroom. In most European countries, educational reforms point clearly to the integration of technological innovations in the classroom context, although in practical terms the successful implementation of such decisions varies from one country to another. Thus, in the United Kingdom, for example, where such issues have become focal points in the national curriculum, the positive dimension of modern technology in education is evident as the following extract demonstrates: "Audio, video and information technology all open up a range of new possibilities for communicative activities such as accessing reference data, using word processors to re-draft text and analyse language, and communicating via international electronic mail-boxes with schools in other countries. (...) All these activities within the language classroom should be embedded in the framework of the school's policy on cross-curricular education" (National Curriculum Modern Languages Working Group: Initial Advice 1.8). Also, in the Netherlands, the Dutch Ministry of Education set up several projects to stimulate the introduction of computers into secondary schools and to provide courses for the training of teachers in computers (cf. Bongaerts et al., 1988).

Similarly, in Spain, despite an immense shortage of technical and financial resources, the latest changes in the national education system known as 
LOGSE (Ley Orgánica de Ordenación General del Sistema Educativo) point to the incorporation of modern information technology in schools. This is clearly emphasized in the Boletín Oficial del Estado which states that: "La vertiginosa rapidez de los cambios cultural, tecnológico y productivo nos sitúa ante un horizonte de frecuentes readaptaciones, actualizaciones y nuevas cualificaciones. La educación y la formación adquirirán una dimensión más completa de la que han tenido tradicionalmente, transcenderán el período vital al que hasta ahora han estado circunscritas, se extenderán a sectores con experiencia activa previa, se alterarán con la actividad laboral. La educación será el principio básico del sistema educativo" (MEC, 1990; BOE del 4-X1990). In this respect, a number of educational bodies have already become engaged in the task of adapting the learning activity to the latest changes in communication networks. One may mention, as a case in point, the efforts of the Spanish Universidad Nacional de Educación a Distancia and its commitment to the development of computer software as an aid for distance language learning although a great deal remains to be done in this area to take full advantage of the multimedia technology for purposes of open and distance learning.

It is perhaps in the Federal Republic of Germany where changes involving the incorporation of information technology in schools have significantly taken place. In Germany, education, especially in matters of school structure, organization and curricula, is the responsibility of the individual states (Länder). In 1984, following an extensive cooperation between the Federal Ministry of Education and Länder governments, the joint Bund-Länder Commission for Educational Planning and Research Promotion paved the way for the creation of what became known as the overall concept whose aim is to ensure that all pupils between 13 and 15 years of age receive basic information training as part of their general education (Hasemann, 1992).

One interesting aspect of the German experience is that the provision of computer training for both the teachers and the pupils is reinforced by the awareness of other negative aspects of computer technology. The purpose of this exercise is "... to impart certain 'computer maturity', and not simply to teach the application and handling aspects of computers. Pupils should be familiarised with individual areas, effects and risks of the application of computers, as it transpires more and more that it is, in fact, more important for a computer operator to be knowledgeable about the subject he is treating with the aid of a computer, than to know about the computer itself" (ibid., p. 226). In short, these are only instances of some of the official measures undertaken in a number of European countries to promote the incorporation of information technology in education. 


\section{THE ROLE OF THE COMPUTER}

The computer can play a variety of roles in the process of language learning. Mohan (1992), for example, considers three models of the role of the computer in second language learning in his discussion of appropriate use of computers, namely the computer as a language teacher; as a stimulus for talk; and as a context for cognitive language development. Each of these is assessed and evaluated under three criteria: testability, consistency with research in language development, and appropriacy in the use of computer resources. As for the first model, Mohan argues that it is defensible despite a number of attacks. It also raises the issue of when formal teaching is appropriate, and the question about how "computer resources can be used for this purpose with elegance and power" (p. 124). It appears that learners are inclined to interact more among themselves than with the teacher and that future research on interaction at the computer may prove useful.

Mohan, however, finds that the role of the computer as a stimulus for talk may not be entirely appropriate or as natural as ordinary conversation. As for the third model, he argues that the computer may prove appropriate as a means for the development of cognitive-academic language proficiency. The author concludes that "to explore alternative models of the role of the computer is to see further possibilities for research and development and to reflect on the assumption of research in language learning in general" (p. 124).

The idea that the computer is there to substitute the teacher is rather unsubstantiated; the role of the teacher is vital in the teaching of a language. Johns (1986: 151) has made it clear: ".... CALL should, if it is to make maximum use of the possibilities opened up by the new technology, involve more than simply making the computer a sort of surrogate teacher or trainer ..., it offers both language learners and language teachers a research tool for investigating 'the company that words keep' that has hitherto usually been available only on mainframe computers to academic researchers in such fields as computational linguistics, lexicography, and stylistics."

The use of the computer in language learning has been restricted to a variety of activities involving primarily drills of all sorts. In fact, software developers, working almost entirely on their own, have produced a whole range of material aimed exclusively at the lexical and grammatical levels with what appears to be a mechanical view of learning. Repetitive tasks, multiple choice exercises based on 'Wrong, Try Again' format, vocabulary, and gap-filling have dominated the scene of the computer in the classroom. While it is true that such CALL packages can, as Chester (1990: 5) put it, “... help to diminish teachers'time spent on routine grammar and lexis, and indeed do offer some prospect of a re- 
medial resource for those teachers who see students' grasp of grammar being increasingly unsatisfactory", it is rather a narrow view to perceive the use of the computer exclusively as a range of structural drills and practices. As will be discussed below, there are indeed other culturally-oriented programs with a communicative outlook to leaming which do appear to have far-reaching results.

\section{TOWARDS A HUMANISTIC APPROACH TO LEARNING}

Part of the criticism directed at the use of the computer in the learning activity involves the abundance of computer software designed and based on a mechanistic view of learning which has its origin in the behaviorist approach. Such material seems to be devoid of the communicative aspect of language the basis of human interaction. Instead, it consists of rather monotonous and repetitive tasks (Ahmad et al., 1985). The lack of a theoretical basis for the development and implementation of CALL materials in language learning activities is an area which continues to preoccupy a growing body of researchers. Although there has been a great deal of ambitious pioneering work in the language and computer area, relatively little has been done in the design of a theoretical framework for the integration of the computer in the language classroom, a framework which embodies both technical aspects of information technology and language learning theory. More than often, language computer programs are designed and implemented without any theoretical considerations. $\mathrm{Ng}$ and Olivier (1987:1) rightly point out that "curriculum developers and instructional designers, concerned with the quality and efficiency of language learning, and aware of the penetrating technology, work in an absence of guiding principles". One consequence of this state of affairs is that evaluation - a keyword in any learning activity - becomes a rather absurd concept. What is clearly needed, as Kohn (1993: 68) explains "is a holistic approach, which sets out to integrate technology development into the broader context of human communication and language learning in such a way that it is made subordinate to the requirements of the human learner."

Far from criticizing or, indeed, praising any particular language learning approach or method (each has its own merits and defects), one can point out, however, that an alternative to the behaviorist concept of learning can be found in what is referred to as the humanistic approach advocated by a number of writers (cf. Kohn, 1993; Stevens, 1992; Graham, 1986; Papert, 1980). In such an approach, emphasis is made particularly on developing the ability to communicate and share one's values and opinions in the learning process. According to Rivers (1981:89), the humanistic approach has resulted in the incorpo- 
ration in language learning materials of vocabulary and activities for developing a better understanding of others' feelings, and for sharing one's values and viewpoints with others. "With this re-emphasis on individual worth and difference, language teachers became conscious of the fact that individual students prefer different modalities of learning ... they also learn at different rates and employ quite different strategies for understanding and retaining the material to be learned. With this new understanding teachers were no longer satisfied with a monolithic 'what is good for one is good for all' approach" (ibid.). Viewed along these humanistic lines, the learning activity becomes part of the socialization process of the learners and may therefore lead to beneficial results socially and academically. Kohn (1993), on he other hand, stresses that computer-assisted language learning is not only about technology but it is also and foremost "about human beings - their cognitive power to creatively acquire and learn a second language for communication purposes, and about the socio-psychological forces shaping the intent, direction and manifestation of the individual learner's learning activity" (p. 68).

\section{Sociocultural dimensions OF CALL}

As argued in the previous section, many studies have so far emphasized the practical and structural aspects surrounding the use of the computer in language learning. These activities involved tasks such as "... teach and reinforce grammatical structures by drill and practice, ... to develop reading, writing and comprehension skills, to give rapid feedback on aura work, ... to develop translation skills, and as an important tool in the development of supported self-study work" (Allan, 1990: 73). Yet, little or practically no attention has been directed to what is referred to here as the sociocultural dimension of CALL, namely attitudinal/motivational orientation and cultural awareness. Under the above heading, the main argument evolves around the question of how the integration of the computer in education, especially in the language course may influence the learning process and contribute to an improvement of the linguistic and cultural context in which it is employed. Three areas will be highlighted below in relation to CALL: language attitudes, cultural awareness, and gender issues.

\subsection{CALL and language attitudes}

Attitudes and motivation are undisputed elements in successful language learning. Various studies have stressed the importance of attitudinal factors and 
how they determine successful acquisition of a foreign language. It has often been indicated, for instance, that learners who have favourable attitudes towards a language and towards its speakers and their culture tend to be more successful in their learning than those who have negative attitudes (Gardner and Lambert, 1972; Burstall et al., 1974; Gardner, 1985). There are, however, other variables which might account for individual differences in L2 learning. Evidence from empirical research suggests that teaching methodology, age, aptitude and verbal intelligence should all be taken into account. The importance of societal factors such as socio-economic grouping, parental support, and the attitudes of the learner, the teacher and the learner's peers and parents is also widely recognized. One may even include other factors such as personality with its components namely, the presence or absence of extroversion, confidence and perseverance, which are likely to influence the learner's achievement. All these dimensions have been subject to much study and debate.

Motivation can play a particularly significant role in the learning of a foreign language. Researchers in this area have distinguished at least two types of motivation, viz. instrumental which is characterized by a desire to gain economic or professional advantages, and integrative which reflects a willingness or desire to become associated with the target language group (cf. Gardner and Lambert, 1972). In a survey of young people in Europe carried out by the Commission of the European Communities in 1987, it was reported that $29 \%$ wanted to learn more languages to increase their career possibilities, while $14 \%$ wanted them in order to live, work, or study. The largest category, $51 \%$, however, were motivated by 'personal interest' (Cook, 1991: 73). A more recent survey by the same commission revealed that $61 \%$ of young Europeans felt that learning a foreign language is very important, while $36 \%$ thought it was useful to learn other languages (Commission of the European Communities, 1993b).

Motivation may be cultivated in the learners by stressing the academic and professional benefits they may derive from knowledge of a second language, and also through cultural exchanges. There already exist some ways of exposing the learner to authentic situations in the foreign language such as the annual school trip and individual exchanges during the summer holidays. Even in the classroom context such exposure is made possible in a few schools with the help of the foreign language assistant. All this gives the learner a good opportunity for direct contact with the target language. There is, however, a further development in this area using the computer and the electronic communication tools. Bus and Austin (1992: 51) have argued that the potential of the electronic media as a means of providing regular access to authentic texts and real language exchanges with pupils abroad are still to be explored. One example of such exchanges is the well established International Newspaper Days which in- 
volves the transmission of materials via the computer. Through Campus electronic mail, pupils from three European countries- France, Germany and Spain- exchanged information and articles to produce a newspaper to be circulated to the participants.

\subsection{Language and cultural awareness}

A small number of initiatives have already been taken in some European countries primarily to promote linguistic and cultural awareness among the learners. One instance of such activities is the European Studies Project (Bus and Austin, 1992), a six-year development program (1986-1992) involving contact between schools in the United Kingdom, Ireland, Belgium, France and Germany. Such contact is essentially based on a whole range of communication modalities such as the use of electronic mailing, satellite and computer conferencing for the exchange of all sorts of information among the participating schools. Although the initial emphasis was on European awareness rather than language, the exchange of information on issues such as the environment or, more generally, social studies involved the use of different languages. In fact, in 1991, a modern language unit was introduced for 14-16 year old pupils who used electronic mailing to exchange details about their education and family backgrounds. The immediacy of contact offered through e-mail seems to be a great advantage for keeping pupils' motivation and interest in knowing more about their friends in other schools in the UK, France, or Belgium. Thus, the use of electronic resources such as computer communication software to establish and maintain contact with learners from distinct cultural and linguistic backgrounds can enhance the learning activity and enrich and diversify the content of the school curriculum. Certainly, the basic use of a word-processor with all the associated routine activities such as planning, checking layouts, grammar and styles and spelling, can improve writing skills (cf. Pennington, 1993).

Another concrete example of appropriate use of the computer to improve cultural awareness is the Northern Ireland context where most Catholic and Protestant children attend separate schools (cf. Pritchard and Loulidi, 1994; Smith and Robinson, 1992; Loulidi, 1990b). Relatively recent legislation involving educational reforms introduced a number of changes in the system. One of these is the introduction of two themes known as Education for Mutual Understanding (EMU) and Cultural Heritage, which are taught on a cross-curricular basis in primary and secondary schools. The aim, of course, is to ameliorate relations between the two communities and enhance communication 
and understanding. In this situation of conflict, the role of the computer as an instrument for contact between schools of distinct denomination becomes particularly relevant. A number of Protestant and Catholic schools from both Northern Ireland and the Republic of Ireland already form part of a computer network through which exchange of information via electronic mail takes place. One objective of such exchange is to familiarize pupils from the two communities with each other's cultural background.

\subsection{CALL and gender issues}

Another area in which the computer may have an influential role in changing learners' attitudes to language learning is the differences in the perception of foreign language learning between girls and boys. In the United Kingdom, and perhaps in other English speaking countries, one of the concerns for a large body of educators and language teachers is the imbalance in the number of boys and girls in the language classroom (Loulidi, 1993; Powell, 1986). Generally, languages seem to appeal more to the girls than to the boys. One reason for this state of affairs is the negative attitudes associated with learning a foreign language among the boys. It has emerged from research studies that boys and girls, in general, have different attitudes towards language learning. Girls, we are repeatedly told, tend to show significantly more positive attitudes than boys do. The findings of Burstall and her co-workers (1974), for instance, confirmed that the attitudes of the girls learning French were consistently more favourable than those of the boys. This finding which has been corroborated in other research studies (cf. Pritchard 1987, Loulidi, 1990a) has been interpreted as stemming essentially from society which prescribes different norms for each of them. It appears that in many contexts, language learning does not seem to conflict with society's norms for girls, whereas it does for boys (cf. Loulidi, 1993, McDonough, 1981).

The idea that French, perhaps the most widely taught language in the UK, is generally regarded as 'feminine' may explain the unpopularity of this language among the boys. It is true that in the popular imagination French is usually 'associated with fine wines, good cooking, haute couture and luxurious perfumes - all either "domestic" or "feminine" in orientation' (Pritchard, 1987: 69). This, it has been suggested, may be seen by boys as incompatible with their emerging masculinity. However, it is important to note that the perception of French as a feminine language seems to differ from one society to another. The findings of Carroll's international study of achievement in French (Carroll, 1975) suggest that there may probably exist a stereotype of femininity asso- 
ciated with the French language in English-speaking countries but not perhaps in other countries. Against this background, one may argue that the integration of the computer in the language classroom may assist in changing some of the negative attitudes and stereotypes associated with language leaming.

\section{SUMMARY AND CONCLUSION}

In short, the major argument in the present article evolved around the idea of integrating the computer in the classroom as an instrument for changing the learners' attitudes, improving their motivation and increasing their linguistic and cultural awareness. As has been discussed above, the computer can play an important role in all these areas. It seems that information technology in general has made long strides in assisting with the general learning activity. However, it still hasn't been fully employed in education. There still persist various obstacles among which:

(1) the shortage of financial and technical resources in the vast majority of schools. The relatively elevated costs of computer hardware and software and the absence of technical and trained personnel to install and guarantee the smooth running of the equipment often make some educational authorities reluctant to consider the use of the computer.

(2) the incompatibility of electronic materials between the schools. For network communication between schools in different European countries, perhaps the fact that there are no standardized norms governing which type of equipment to use poses some technical impediments. The discrepancies in the systems used are quite sharp. There is, for instance, a predominance of BBCs and Nimbuses in many schools in the United Kingdom, of Commodores in Germany, and of a variety of IBM Compatibles in Spain. Problems of compatibility will inevitably arise (cf. Ruiperez, 1990: 51-52).

(3) teachers' skepticism. As discussed above, there are still many teachers whose skeptical attitudes to the computer make them reluctant to use the computer in their classrooms. Teachers may well explore the potentials of such machines in the hope of improving the teaching and learning of languages. As Green (1991: 62) puts it "If a teacher has the confidence to try something new in the genuine belief that it will improve the learning capacity of the class, enhance the enjoyment of the subject and create a better learning environment then I feel that the risk is worth taking." 
Far from advocating the integration of the computer in the language course as a teacher substitute, the present article stresses that information technology in education should be used as an instrument, a teaching aid which could be positively employed in the classroom to enhance the learning process.

\section{BIBLIOGRAPHY}

AhMad, K.; Corbett, G.; Rogers, M. and Sussex, R. (1985): Computers, Language Learning and Language Teaching. Cambridge: Cambridge University Press. AllaN, JAONNA, (1990): "Evaluating CALL". Language Learning Journal 2, 73-74. Bongaerts, Theo; HaAn, Pieter de; Lobbe, Sylvia; and Wekker, Herman (eds.) (1988): Computer Applications in Language Learning. Dordrecht: Foris Publications.

BUND-LÄNDER-KOMMISSION FUR BILDUNGSPLANUNG UND FORSCHUNGSFÖDERUNG, Gesamtkonzept $f, r$ die informationstechnische Bildung (Bonn, 1987).

Burstall, C., Jamieson, M., Cohen, S. and Hargreaves, M. (1974): Primary French in the Balance. Windsor: NFER.

Bus, R. and Austin, R. (1992): "Campus 2000 in modern languages". Language Learning Journal 5, 51-52.

CARROLL, J.B. (1975): The Teaching of French as a Foreign Language in Eight Countries. Stockholm: Almquist and Wiksel.

CHESTER, G. (1990: "Computer in modern language teaching: a brief overview". ReCALL software guide, N/ 2, 4-7.

Commission of the European Communities (1993a): Foreign Language Learning and the Use of New Technologies. Conference Proceedings, London 1993. Brussels: Bureau LINGUA.

Commission of the European Communities (1993b): Intercambios de JÛvenes en la Comunidad Europea. Luxembourg: Office for Official Publications of the European Communities.

CooK, V. (1991): Second Language Learning and Teaching. London: Edward Arnold.

DOBBERSTEIN, M. (1993): "Computer literacy for the rest of us". Computer and the Humanities 27 (5-6), 429-433.

GARDNER, R. C. (1985): Social Psychology and Second Language Learning: The Role of Attitudes and Motivation. London: Edward Arnold.

GARDNER, W. C. and LAMBERT, W. E. (1972): Attitudes and motivation in second language learning. Rowley, Mass.: Newbury House.

Graham, H. (1986): The Human Face of Psychology: Humanistic Psychology in its Historical Social and Cultural Context. Milton Keynes: Open University Press. 
GREEN, J. (1991): "Experimenting with CALL". Language Learning Journal 3, 61-62. HASEMANN, K. (1992): "The rôle of the federal government in the introduction of information technology teaching into schools of general education in the Federal Republic of Germany". Education and Computing 8 (3), 225-228.

JoHNs, T. (1986): "Micro-concord: a language learner's research tool”. System 14 (2), 151-162.

KOHN, K. (1993): "Five principles of CALL research and development in a holistic approach". In Commission of the European Communities, Foreign Language Learning and the Use of New Technologies. Conference Proceedings, London 1993. Brussels: Bureau LINGUA, pp.67-71.

LoUliDI, R. (1993): "Gender issues in language learning: the socio-cultural argument". In the proceedings of the International Conference of Applied Linguistics, vol. II. Instituto de Ciencias de la Educacion: University of Granada, pp. 30-38.

LOULIDI, R. (1990a): "Is language learning really a female business?". Language Learning Journal 1, 40-43.

LoUliDI, R. (1990b): "Attitudes towards foreign language learning in Protestant and Catholic schools in Northern Ireland". Language Culture and Curriculum 3 (3), 227-238.

MEC (Ministerio de Educación y Ciencia) (1990): Ley Orgánica de Ordenación General del Sistema Educativo. Madrid.

MoHAN, B. (1992): "Models of the role of the computer in second language development". In M.C. Pennington and V. Stevens (eds.), pp. 110-126.

NG, K. EVElyN, K.L. and OliviER, WILliam P. (1987): "Computer assisted language learning: an investigation on some design and implementation issues". System $15(1), 1-17$.

PAPERT, S. (1980): Mindstorms: Children, Computers, and Powerful Ideas. New York: Basic Books.

Pennington, M.C. and Stevens, V. (eds.) (1992): Computers in Applied Linguistics. Clevedon: Multilingual Matters.

Pennington, M.C. (1993): "Exploring the potential of word processing for non-native writers". Computers and the Humanities 27 (3), 149-163.

POWELL, B. (1986): Boys, Girls and Languages in School. London: CILT.

PrITCHARD, R.M.O. (1987): "Boys' and girls' attitudes towards French and German". Educational Research 29 (1), 65-72.

PrITChARD, R.M.O and Loulidi, R. (1994): "Some attitudinal apects of foreign language learning in Northern Ireland: focus on gender and religious affiliations". British Journal of Educational Studies 42 (4), 388-401.

RIVERS, W. (1981): Teaching Foreign Language Skills. Chicago: The University of Chicago Press.

RUIPÉREZ, G. (1990): Introducción a la Enseñanza de Lenguas Asistida por Ordenador. Madrid: UNED. 
SMITH, A. and RoBINSON, A. (1992): Education for Mutual understanding: Perception and Policy. University of Ulster: Centre for the Study of Conflict.

Stevens, V. (1992): "Humanism and CALL: a coming of age". In M.C. Pennington and V. Stevens (eds.), pp. 11-38. 